\title{
EFEK GANDA DAN PERMINTAAN KONSUMEN OBJEK WISATA DANAU WISATA SEJARAH SEBEDANG DI DESA SEMPALAI KECAMATAN SEBAWI KABUPATEN SAMBAS
}

\author{
(Double Effects And Consumer Requests Danau Wisata Sejarah Sebedang Sempalai Village, \\ Sebawi District, Sambas Regency)
}

\author{
Ahmad Aris, Gusti Hardiansyah, Erianto \\ Fakultas Kehutanan Universitas Tanjungpura Pontianak.Jalan Imam Bonjol Pontianak 78124 \\ Email: toparis99@gmail.com
}

\begin{abstract}
Danau Wisata Sejarah Sebedang (DWSS) is one of the tourist attractions located in Sambas district. Most of the economic impacts that exist on these attractions are not widely known. Therefore, there is a need for research to determine the economic value and factors that influence tourism demand for this tourist attraction. The purpose of this research is to analyze the economic impact felt by the surrounding community. To achieve the research objectives used the Travel Cost Method and the Keynesian multiplier. The object of research is visitors who come to DWSS, business units and local workforce. Visitors of Sebedang Lake tourism objects are generally dominated by community groups aged 25 years - 35 years, with high school education level and equivalent, their income level is more than Rp. 2,000,000.00 per month. The factors that influence recreational demand to DWSS are travel costs and travel time. The average tourist expenditure is $R p$. 56,295.00 with 3,253 monthly visits. The existence of this DWSS object has an economic impact on the local community around, such as the direct economic impact in the form of business unit owner's income, which is 66\%. While the indirect impact in the form of labor income is $1 \%$. Then the further impact is in the form of labor expenditure of 59\% which is used for food needs. The Keynesian lncome Multiplier value is 2.64, Type 1 Ratio Income Multiplier is 1.19 and Type 2 Ratio Income Multiplier is 1.21.
\end{abstract}

Keywords : Sebedang Lake,economic impact, Natural Recreation

\section{PENDAHULUAN}

Kegiatan pariwisata secara potensial dapat memberikan efek ke depan maupun ke belakang. Setidaknya ada tiga keuntungan yang dapat diperoleh dengan semakin berkembangnya kepariwisataan suatu daerah. Pertama, akan memberikan sumbangan yang cukup bagi pendapatan masyarakat. Kedua, mampu mengurangi jumlah pengangguran karena daya serap tenaga kerjanya yang cukup besar dan merata. Ketiga, mendorong timbulnya wirausahawan yang bergerak di industri pariwisata, baik langsung maupun tidak langsung. Tujuan akhir pembangunan sektor kepariwisataan adalah untuk memperbesar output atau nilai tambah. Hal ini sesuai dengan perkembangan ekonomi karena nilai tambah adalah salah satu indikator yang dipergunakan untuk mengukur pertumbuhan ekonomi (Sigit, 1994).

Salah satu Wisata Alam yang terdapat di Kabupaten Sambas adalah 
Danau Wisata Sejarah Sebedang (DWSS). Berdasarkan Keputusan Menteri Kehutanan dan Perkebunan Nomor: 259/KPTS-II/2000, kawasan Danau Sebedang merupakan kawasan yang termasuk sebagai Areal Penggunaan Lain (APL), dengan luas areal perairannya $\pm 65 \mathrm{Ha}$. Berdasarkan PP RI No. 61 Tahun 2012 tentang perubahan atas PP No. 24 Tahun 2010 Tentang Penggunaan Kawasan Hutan, bunyi pasal 4 ayat (1) mengatakan bahwa penggunaan kawasan hutan untuk kepentingan pembangunan di luar kegiatan kehutanan hanya dapat dilakukan untuk kegiatan yang mempunyai tujuan strategis yang tidak dapat dielakkan. Kegiatan yang mempunyai tujuan strategis adalah kegiatan yang diprioritaskan karena mempunyai pengaruh yang sangat penting secara nasional terhadap pertumbuhan ekonomi, sosial, budaya dan lingkungan, sehingga suatu tempat wisata alam yang dapat mendukung pertumbuhan ekonomi negara dapat dijadikan sebagai kawasan wisata dengan tetap menjaga keseimbangan dari lingkungan tersebut (Robihah. 2014).

Kehidupan masyarakat sekitar yang berada di kawasan DWSS ini sebagian besar masyarakatnya adalah petani. Seiring dengan maraknya perkembangan wisata, kehidupan masyarakat di sekitar kawasan ini mengalami pergeseran baik dari aspek sosial, ekonomi, maupun lingkungan. Pergeseran aspek ekonomi terlihat dari kegiatan ekonomi yang dilakukan masyarakat seperti mendirikan usahausaha yang menunjang wisata maupun menjadi pekerja wisata yang dianggap lebih menjanjikan dari segi pendapatan.

Pengeluaran wisatawan selama melakukan perjalanan wisata akan mendorong terciptanya transaksi ekonomi bagi sektor-sektor penyedia barang dan jasa. Adanya transaksi tersebut akan menimbulkan dampak pengganda bagi sektor ekonomi yang lainnya. Masyarakat lokal di sekitar kawasan danau pada umumnya mempunyai tingkat penghasilan menengah ke bawah sehingga perlu adanya usaha untuk memperbaiki taraf hidup bagi mereka.

Penelitian ini bertujuan untuk: (1) Mengidentifikasi karakteristik pengunjung, unit usaha, tenaga kerja di Danau Wisata Sejarah Sebedang (DWSS), (2) Mengkaji faktor-faktor yang mempengaruhi permintaan wisata ke (DWSS), (3) Menganalisa dampak ekonomi yang ditimbulkan oleh kegiatan wisata alam terhadap pendapatan masyarakat di sekitar obyek DWSS yang memiliki lapangan usaha maupun yang bekerja di lokasi wisata tersebut.

\section{METODOLOGI PENELITIAN}

Penelitian ini dilakukan di kawasan Danau Sebedang Desa Sempalai Kecamatan Sebawi Kabupaten Sambas Provinsi Kalimantan Barat. Pengambilan data di lapangan dari tanggal 17 Oktober sampai dengan 11 November 2016. Objek penelitian adalah pengunjung yang datang ke DWSS sebanyak 80 orang dan 
responden unit usaha dan tenaga kerja lokal masing-masing 20 dan 10 orang. Responden tersebut diambil dengan menggunakan teknik purposive sampling.

Metode yang digunakan dalam pengumpulan data adalah dengan menggunakan metode survey. Data primer yang diambil yaitu karakteristik dan sosial ekonomi pengunjung, pendapatan dan pengeluaran unit usaha, serta tenaga kerja lokal di lokasi. Data primer didapatkan dari hasil wawancara yang dilakukan secara lisan dengan menggunakan kuisioner, serta observasi yang dilakukan dengan mengamati, mencatat dan mendokumentasikan. Data sekunder didapat dari studi literatur dan pengelola kawasan. Analisis kunjungan ke objek Danau Sebedang yang dipengaruhi oleh biaya perjalanan, umur pengunjung, penghasilan rata-rata pengunjung, jarak, waktu dan pengalaman individu pengunjung, dapat diformulasikan sebagai berikut:

$$
\begin{aligned}
& Y=f\left(X 1, X_{2}, X_{3}, X_{4}, X_{5}, X_{6},\right. \\
& \left.X_{7},\right)
\end{aligned}
$$

Keterangan :

$\mathrm{Y}=$ Jumlah permintaan wisata ke objek wisata Danau Sebedang

$\mathrm{X}_{1}=$ Biaya perjalanan ke objek wisata

Danau Sebedang (Rp.)

$\mathrm{X}_{2}=$ Pendapatan per bulan (Rp.)

$\mathrm{X}_{3}=$ Umur responden $(\geq 17$ tahun $)$

$\mathrm{X}_{4}=$ Waktu tempuh (Menit)

$\mathrm{X}_{5}=$ Jumlah tanggungan Keluarga

(Orang)
$\mathrm{X}_{6}=$ Jumlah rombongan atau kedatangan ke tempat wisata Danau Sebedang (Orang)

$\mathrm{X} 7$ = Pengetahuan pengunjung (tahu atau tidak tahu)

Menurut META (2001), dalam mengukur dampak ekonomi pariwisata terhadap perekonomian masyarakat lokal terdapat dua tipe pengganda, yaitu

1. Keynesian Local Income Multiplier, yaitu nilai yang menunjukkan berapa besar pengeluaran pengunjung berdampak pada peningkatan pendapatan masyarakat lokal.

2. Ratio Income Multiplier, yaitu nilai yang menunjukkan seberapa besar dampak langsung yang dirasakan dari pengeluaran pengunjung berdampak terhadap perekonomian lokal.

Pengganda ini mengukur dampak tidak langsung dan dampak terusan. Menurut META (2001), secara matematis dapat dirumuskan :

Keynesian Income Multiplier $=\frac{\mathrm{D}+\mathrm{N}+\mathrm{U}}{\mathrm{E}}$ Ratio Income Multiplier, Tipe $I=\frac{\mathrm{D}+\mathrm{N}}{\mathrm{D}}$ Ratio Income Mtrlfiplier, TipeII $=\frac{\mathrm{D}+\mathrm{N}+\mathrm{U}}{\mathrm{D}}$ dimana:

E : Tambahan pengeluaran pengunjung (rupiah)

D : Pendapatan lokal yang diperoleh secara langsung dari E (rupiah)

$\mathrm{N}$ : Pendapatan lokal yang diperoleh secara tidak langsung dari E (rupiah)

$\mathrm{U}$ : Pendapatan lokal yang diperoleh secara induced dari E (rupiah) 
HASIL DAN PEMBAHASAN

\section{Karakteristik Responden}

Data pengunjung Danau Wisata Sejarah Sebedang yang dipilih sebagai

\section{Tabel 1. Karakteristik Responden (Resp}

\begin{tabular}{|c|c|c|c|}
\hline No & Kategori/Tingkatan & Jumlah/org & Persentase $(\%)$ \\
\hline \multirow[t]{3}{*}{1} & Jenis Kelamin & & \\
\hline & a. Laki-laki & 46 & 57,5 \\
\hline & b. Perempuan & 34 & 42,5 \\
\hline \multirow[t]{5}{*}{2} & Umur (Tahun) & & \\
\hline & a. $<25$ & 30 & 37,5 \\
\hline & b. $25-35$ & 36 & 45 \\
\hline & c. $36-45$ & 12 & 15 \\
\hline & d. $>45$ & 2 & 2,5 \\
\hline \multirow[t]{5}{*}{3} & Pendidikan Terakhir & & \\
\hline & a. SD & 4 & 5 \\
\hline & b. SLTP & 11 & 13,75 \\
\hline & c. SLTA & 29 & 36,25 \\
\hline & d. Perguruan Tinggi & 36 & 45 \\
\hline \multirow[t]{6}{*}{4} & Peekerjaan & & \\
\hline & a. PNS & 21 & 26,25 \\
\hline & b. Karyawan Swasta & 8 & 10 \\
\hline & c. Pelajar & 16 & 20 \\
\hline & d. Buruh & 23 & 28,75 \\
\hline & e. Lainnya & 12 & 15 \\
\hline \multirow[t]{5}{*}{5} & Pendapatan & & \\
\hline & a. $<500.000$ & 16 & 20 \\
\hline & b. $600.000-1.500 .000$ & 14 & 17,5 \\
\hline & c. $1.600 .000-2.500 .000$ & 22 & 27,5 \\
\hline & d. $2.600 .000-3.500 .000$ & 21 & 26,25 \\
\hline \multirow[t]{6}{*}{6} & Daerah asal & & \\
\hline & a. Sambas & 36 & 45 \\
\hline & b. Singkawang & 19 & 23,75 \\
\hline & c. Bengkayang & 11 & 13,75 \\
\hline & d. Mempawah & 5 & 6,25 \\
\hline & e. Pontianak & 7 & 8,75 \\
\hline
\end{tabular}

Sumber: HasilPenelitian 2016

Berdasarkan sebaran umur, tahun dengan komposisi 42,5\%. Mereka sebagian besar responden pengunjung kebanyakan sudah berkeluarga dan Danau Sebedang berusia antara 25-35 mempunyai tanggungan. Latar belakang

responden sebanyak 80 orang, yang terdiri atas responden pria dan wanita, dengan komposisi $57,5 \%$ pria dan 42,5 $\%$ wanita. 
pendidikan SLTA Sederajat yaitu sebesar $36,25 \%$. Selanjutnya pendidikan perguruan tinggi sebesar $45 \%$. Sebagian besar pengunjung objek wisata Danau Sebedang adalah Pegawai Negeri Sipil dan Buruh yaitu sebesar 26,25 dan $28,75 \%$. Pengunjung objek wisata Danau Sebedang ini memiliki tingkat pendapatan yang bervariasi. Sebagian besar tingkat pendapatannya menengah ke atas yaitu yang berpenghasilan lebih dari Rp.2.600.000- Rp.3.500.000 per bulan. Setelah itu diikuti oleh pengunjung dengan penghasilan $\mathrm{Rp}$. 500.000,00-Rp.1.500.000,00 per bulan. Sebagian besar pengunjung yang datang ke objek wisata ini berasal dari daerah Kecamatan Sebawi dan sekitarnya yaitu sebesar $45 \%$. Hal ini disebabkan oleh jarak dan waktu tempuh yang relatif lebih singkat untuk menuju ke lokasi. Dengan jarak kurang lebih $10 \mathrm{~km}$ dan waktu tempuh sekitar 20 menit sehingga biaya yang dikeluarkan pun tidak telalu banyak.

Jenis usaha sebagian pemilik unit usaha di objek wisata Danau Sebedang ini adalah warung yaitu sebesar 6 unit. Warung-warung ini terdapat di sepanjang pinggir danau. Sebagian besar warung ini menjajakan makanan ringan dan minuman yang bisa dinikmati oleh wisatawan. Selanjutnya penjual keliling yang berada di sekitar lokasi kawasan yang menjajakan dagangannya pada saat jumlah pengunjung ramai yaitu pada hari sabtu dan minggu, jumlah penjual keliling ini ada 4 unit. Kafe dan rumah makan masing - masing2 dan 4 unit.

Tabel 2. Sebaran Unit Usaha di DWS Tahun 2016 (Distribution of Business Units in DWSS 2016)

\begin{tabular}{lc}
\hline \multicolumn{1}{c}{ Jenis Unit Usaha } & Jumlah (unit) \\
\hline Warung & 6 \\
Rumah makan & 4 \\
Kafe & 2 \\
Tempat Penginapan & 1 \\
Penyewaan Alat & 3 \\
Penjual keliling & 4 \\
\hline
\end{tabular}

Sumber: HasilPenelitian 2016

Pendapatan bersih yang didapat oleh pemilik unit usaha di objek wisata ini, berkisaran Rp.1.000.000,00 sampai Rp. 2.000.000,00 per bulan yaitu sebesar 55\%, sedangkan pendapatan lebih dari Rp. 2.000.000,00 per bulan sebesar $40 \%$ dan sisanya responden dengan tingkat pendapatan kurang dari Rp 1.000.000,00 per bulan yaitu sebesar $5 \%$. Pelaku usaha di objek wisata Danau Sebedang kebanyakan tidak memiliki penghasilan tambahan karena usaha di Danau Sebedang merupakan mata pencaharian utama. 


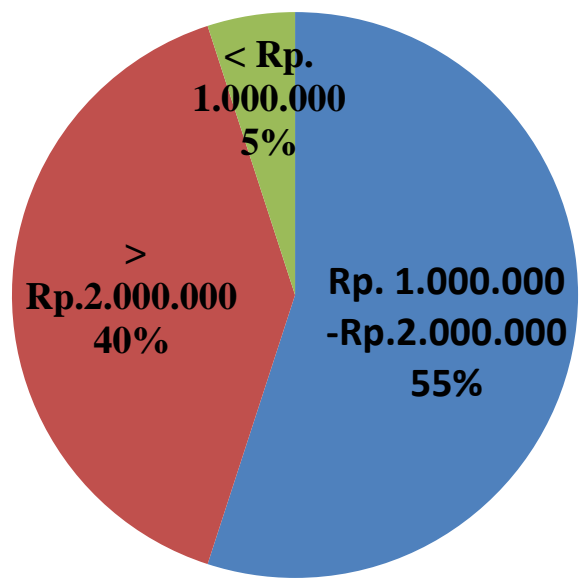

Gambar 1. Pendapatan Bersih Responden Unit Usaha (Net Income of Businnes Units)

Sebanyak 10 responden tenaga kerja yang berada di objek wisata di Desa Sempalai, sebagian besar berasal dari masyarakat lokal sekitar Desa Sempalai sebesar 90\%. Hal ini dikarenakan salah satu tujuan dari pengelolaan lokasi wisata adalah untuk membantu perekonomian masyarakat lokal. Tenaga kerja yang berada di lokasi wisata Danau Sebedang ini terdiri atas warung, rumah makan, tempat penginapan, kafe, dan penjaga loket. Penjaga loket tiket masuk terdiri dari 3 orang, mereka bekerja dengan sistem bergantian (shift). Keterangan untuk jumlah tenaga kerja pada masingmasing usaha dapat dilihat pada tabel 3.

Tabel 3. Jumlah Tenaga Kerja di Kawasan DWSS Tahun 2016 (Total Worker in DWSS 2016 )

\begin{tabular}{lcccc}
\hline Lokasi & Jumlah & Pendapatan $(\mathbf{R p})$ & Hari kerja & $\begin{array}{c}\text { Waktu } \\
\text { kerja }\end{array}$ \\
\hline Warung & 1 & 650.000 & Setiap hari & $7-8$ jam \\
Rumah Makan & 3 & $600.000-700.000$ & $1-2$ hari & 10 jam \\
Tempat Penginapan & 1 & 1.100 .000 & Setiap hari & 10 jam \\
Kafe & 2 & 700.000 & Setiap hari & $5-6$ jam \\
Loket & 3 & $900.000-1.200 .000$ & Setiap hari & 7 jam \\
\hline
\end{tabular}

Sumber: Hasil Penelitian 2016.

Pendapatan per bulan yang diperoleh dari penjaga loket tiket masuk berkisar Rp.900.000- Rp. 1.200.000. Lokasi wisata ini terdapat 4 rumah makan, dimana pegawai rumah makan ini terdiri dari 3 orang. Pendapatan per bulan yang diperoleh dari pegawai rumah makan ini Rp.600.000 Rp.700.000dengan jam kerja 10 jam per hari. Dari 6 warung yang ada di lokasi wisata ini hanya terdapat 1 tenaga kerja yang ada dengan pendapatan Rp.650.000/bulan. Objek DWSS terdapat 1 tempat penginapan sederhana dengan 1 tenaga kerja. Pendapatan yang diperoleh oleh tenaga kerja ini perbulannya $\mathrm{Rp} 1.100 .000$, dengan waktu kerja 10 jam setiap hari. 


\section{Fungsi Permintaan Objek Wisata} Alam Danau Sebedang.

Berdasarkan data yang diperoleh diatas sebelumnya, kemudian dilakukan regresi untuk menghasilkan model permintaan wisata ke danau sejarah sebedang. Model yang digunakan

Tabel 4. Hasil Estimasi regresi liner berganda dan faktor-faktor yang mempengaruhi permintaan wisata di DWSS (Estimatation Results of multiple linear regression and factors that influence tourism demand in DWSS)

\begin{tabular}{lllll}
\hline Variabel & Koef & Std. Error & T & Sig, \\
\hline (Constant) & 6.856 & 1.198 & 5.721 & .000 \\
Biaya Perjalanan (x1) & $3.506 \mathrm{E}-5$ & .000 & 3.180 & $.002^{*}$ \\
Pendapatan (x2) & $-8.521 \mathrm{E}-8$ & .000 & -326 & .745 \\
Umur (x3) & -.057 & .054 & -1.059 & .293 \\
Waktu Tempuh (x4) & -.021 & .007 & -3.111 & $.003^{*}$ \\
Jumlah tnggungan (x5) & -.474 & .352 & -1.347 & .182 \\
Jumlah Rombongan (x6) & -.070 & .267 & -264 & .793 \\
Pengetahuan Pengunjung (x7) & .959 & .647 & 1.481 & .143 \\
\hline
\end{tabular}

R Adjusted

$\mathrm{R} 2$

(*) signifikan pada $\alpha=0.05$

Sumber: Data diolah, 2016.

Berdasarkan table tersebut diperoleh persamaan regresinya sebagai berikut:

$\mathrm{Y}=6.856+0.00003506 \mathrm{X}_{1}-0.00000008521 \mathrm{X}_{2}-0.057 \mathrm{X}_{3}-0.021 \mathrm{X}_{4}-0.474 \mathrm{X}_{5}-0.70 \mathrm{X}_{6}+0.959 \mathrm{X}_{7}$.

Hasil pengujian menunjukkan

bahwa dari tujuh variabel sosial ekonomi yang diamati dalam penelitian ini, terdapat dua variabel yang berpengaruh signifikan $(\alpha=0.05)$ terhadap tingkat kunjungan wisata ke Danau Sebedang. Kedua variabel tersebut yaitu biaya perjalanan, dan waktu tempuh. Koefisien variabel waktu tempuh bertanda negatif, menunjukkan bahwa apabila waktu tempuh semakin dekat, maka jumlah kunjungan akan semakin meningkat. Waktu tempuh ke tempat wisata merupakan sesuatu yang sangat adalah jumlah permintaan wisata yang dipengaruhi oleh frekuensi kunjungan ke Danau Wisata Sejarah Sebedang dengan formula sebagai berikut :

$$
Y=f\left(X_{1}, X_{2}, X_{3}, X_{4}, X_{5}, X_{6}, X_{7}\right)
$$


kunjungan wisatawan. Pola wisatawan yang berkunjung ke Danau Sebedang pada umumnya melakukan perjalanan berwisata secara massal pada akhir pekan dan hari libur nasional terutama libur lebaran dan tahun baru. Periode tersebut sebagian besar masyarakat akan merencanakan perjalanan ke tempattempat wisata terdekat sehingga faktor usia, pendidikan, pendapatan dan jumlah kelompok cenderung tidak menjadi bahan pertimbangan oleh wisatawan.

\section{Dampak Ekonomi Keberadaan Objek Wisata Alam Danau Sebedang}

Menurut Faizun (2009), pariwisata merupakan suatu kegiatan yang secara langsung menyentuh dan melibatkan masyarakat sehingga dapat memberikan berbagai dampak terhadap masyarakat sekitar. Adanya pengembangan pariwisata di suatu tempat sangat berpengaruh pada peningkatan kesejahteraan masyarakat. Azzahra dan Khadiyanto (2013). Dampak ekonomi dari kegiatan pariwisata terhadap kondisi masyarakat, seperti peningkatan atau penurunan pendapatan masyarakat, perluasan lapangan pekerjaan dan perilaku masyarakat terhadap lingkungan sekitarnya. Menurut Anisah dan Riswandi (2015) pengeluaran wisatawan yang dikeluarkan di tempat mereka berwisata, seperti penggunaan jasa transportasi, hiburan, jasa rekreasi, pedagang, makanan dan minuman serta penggunaan jasa akomodasi akan membawa dampak pada perekonomian baik secara langsung, tidak langsung, maupun tidak langsung.

Dampak langsung adalah nilai dari pengeluaran wisatawan dikurangi nilai impor untuk penyediaan produk dan jasa pada bisnis unit usaha yang ada. Dampak ekonomi langsung merupakan manfaat yang langsung dirasakan oleh masyarakat (Vanhove, 2005). Dampak tidak langsung yaitu pendapatan yang diterima oleh pelaku usaha yang memenuhi kebutuhan usaha atau pihak yang menjadi pemasok bagi pelaku usaha yang terlibat langsung dalam sektor pariwisata (Ardahaey, 2011). Dampak tidak langsung yang menjadi indikator dalam penelitian ini adalah aktivitas ekonomi lokal dari pembelanjaan unit usaha penerima dampak langsung. Dampak lanjutan (induced) adalah aktivitas ekonomi lokal lanjutan dari tambahan pendapatan lokal (dampak lanjutan dari dampak langsung dan dampak tidak langsung). Dampak ekonomi yang dihasilkan oleh sektor pariwisata umumnya diukur dari keseluruhan pengeluaran pengunjung untuk keperluan akomodasi, konsumsi, perjalanan, dokumentasi dan keperluan lainnya. Jumlah dari seluruh pengeluaran itu diestimasi dari jumlah total hari kunjungan dari pengunjung dan juga pengeluaran rata-rata per hari dari pengunjung.

\section{a. Dampak Ekonomi Langsung (Direct Impact)}

Wisatawan yang datang ke sebuah destinasi dalam jangka waktu tertentu, menggunakan sumber daya dan fasilitasnya. biasanya mengeluarkan 
uang untuk keperluan tertentu, Hary (2017). Menurut Molden (2001), tidak semua pengeluaran pengunjung dilakukan di objek wisata, ada sebagian dari pengeluarannya yang berasal dari luar objek wisata yang disebut dengan kebocoran ekonomi (economic leakage). Hasil penelitian ini, nilai economic leakage sebesar 0,03 dimana, sebagian pengunjung tersebut banyak dari luar daerah Desa Sempalai. Proporsi pengeluaran yang dilakukan oleh pengunjung terkait dengan unit usaha dan fasilitas rekreasi yang tersedia di lokasi dapat dilihat pada Tabel 5.

Tabe1 5. Proporsi Struktur Pengeluaran Pengunjung DWSS Tahun 2016 (Proportion of Expenditure Structure for DWSS2016)

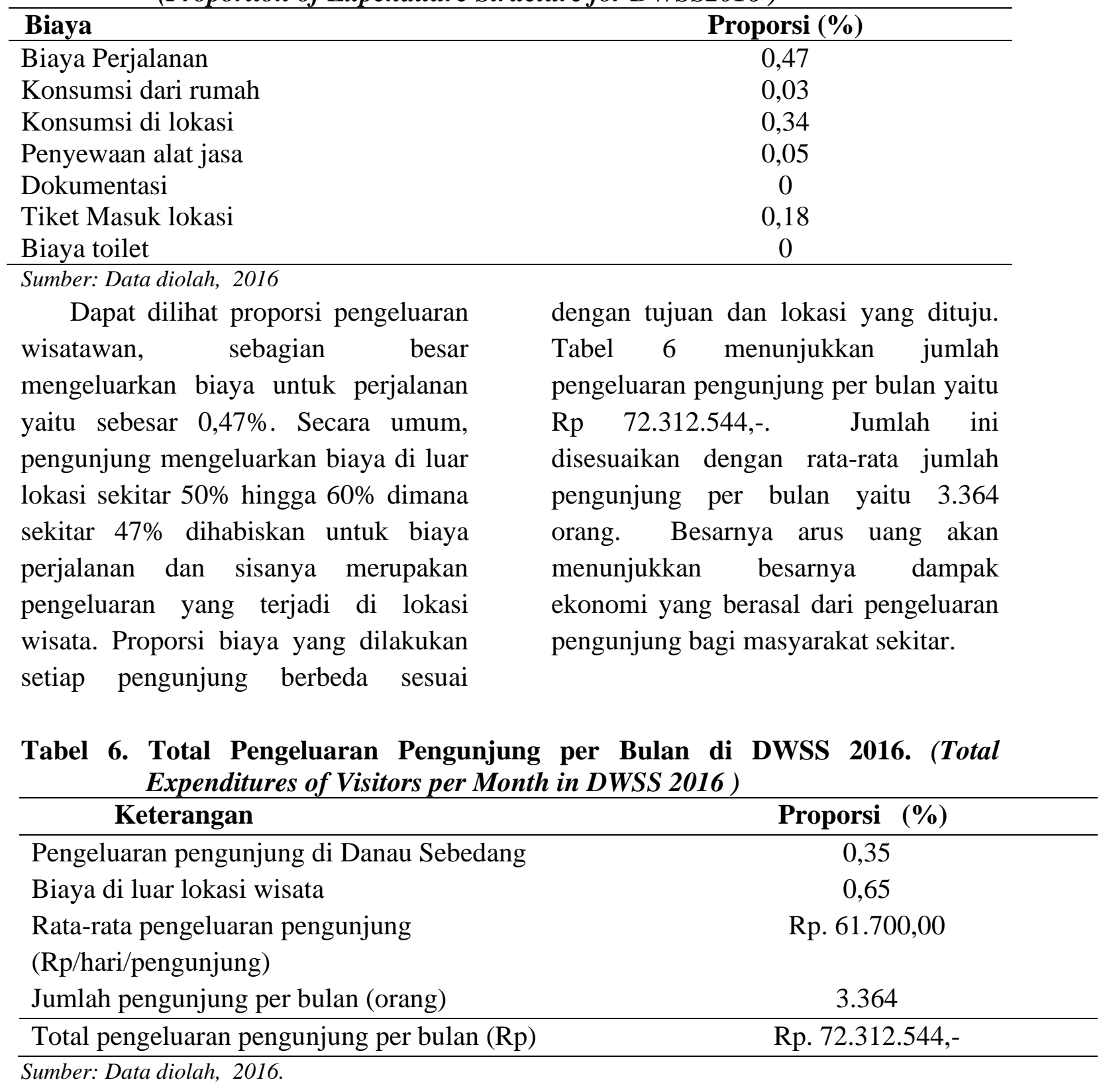


Keberadaan objek wisata dapat membuka peluang bagi masyarakat lokal untuk membuka usaha yang terkait dengan pemenuhan kebutuhan pengunjung selama berada di lokasi. Unit usaha di Danau Sebedang ini, sebagian besar merupakan unit usaha dengan skala kecil dan hanya ramai dikunjungi pada akhir pekan dan hari libur, namun unit usaha yang ada dilokasi cukup banyak. Hal ini dapat

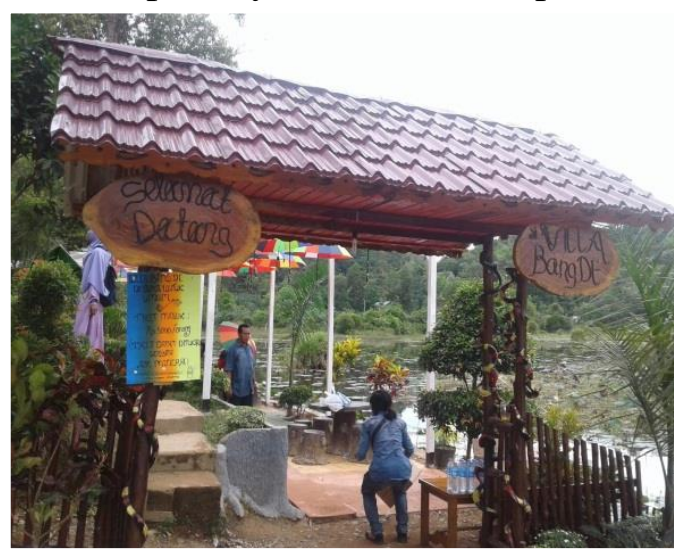

Gambar 2. Villa dan warung di lokasi DWSS (Villa and stalls in DWSS location)

Pendapatan yang dihasilkan oleh pemilik unit usaha yang merupakan hasil dari pengeluaran pengunjung akan digunakan kembali untuk menjalankan aktivitas unit usaha tersebut. Setiap Usaha ini membutuhkan bahan baku dalam produksinya, baik yang berasal dari lokasi wisata ataupun dari luar lokasi wisata. Komponen biaya yang utama dari unit usaha ini adalah biaya pembelian input, upah karyawan, pemeliharaan alat, biaya operasional unit usaha, kebutuhan pangan harian,

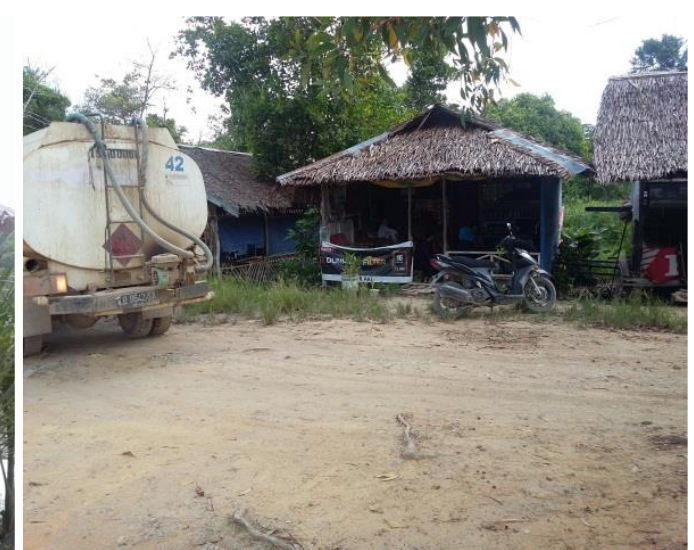

menimbulkan perputaran uang yang terjadi antara pengunjung dan masyarakat lokal yang mempunyai usaha di lokasi tersebut. Sebaran untuk jumlah unit usaha di lokasi danau sebedang yaitu warung yang terdiri dari 6 unit, rumah makan 4 unit, tempat penyewaan ban 1 unit, penyewaan sampan 2 unit, kafe 2 unit, dan tempat penginapan atau Villa 1 unit.

dan transportasi lokal. Proporsi untuk upah tenaga kerja di objek wisata Danau Sebedang ini sangat rendah yaitu 4,79\%. Hal ini disebabkan oleh beberapa faktor yaitu jumlah jam kerja yang masih pendek, objek wisata yang cenderung hanya ramai pada akhir pekan dan hari libur, serta belum maksimalnya pemberdayaan tenaga kerja lokal di lokasi ini. Keterangan untuk Pengeluaran Unit Usaha di Danau Sebedang dapat dilihat pada Tabel 7. 
Tabel 7. Proporsi Pengeluaran Unit Usaha Terhadap Penerimaan Total di DWSS (Proportion of Business Unit Expenditures Against Total Acceptance in DWSS )

\begin{tabular}{lr}
\hline \multicolumn{1}{c}{ Komponen } & Proporsi \\
\hline Pendapatan pemilik & 71,8 \\
Upah Karyawan & 4,79 \\
Pembelian input/bahan baku & 16,05 \\
Biaya pemeliharaan alat & 0,9 \\
Biaya operasional unit usaha (listrik,PAM) & 5,24 \\
Pengembalian kredit ke bank & 0 \\
Kebutuhan pangan harian & 0,93 \\
Transportasi lokal & 0,25 \\
Retribusi dan pajak & 0 \\
Total & $\mathbf{1 0 0}$ \\
\hline
\end{tabular}

Sumber: Data diolah, 2016.

Berdasarkan proporsi terhadap penerimaan total, pengeluaran unit usaha terbesar banyak dihabiskan untuk pembelian bahan input dan upah karyawan. Setelah itu digunakan untuk biaya operasional, kebutuhan pangan harian dan biaya pemeliharaan alat-alat, sedangkan untuk pengembalian kredit ke bank rata-rata pemilik unit usaha tidak ada.

\section{b. Dampak Ekonomi Tidak Langsung (Indirect Impact)}

Keberadaan objek wisata Danau Sebedang ini, dapat membuka peluang bagi masyarakat lokal untuk membuka usaha di lokasi tersebut. Hal ini juga dapat membuka kesempatan kerja baru bagi masyarakat sekitar. Sebagian besar unit usaha di lokasi ini dikelola langsung oleh pemiliknya, ada juga sebagian dari mereka yang mempunyai tenaga kerja pada waktu-waktu tertentu, terutama pada saat akhir pekan dan hari libur, karena pada saat itu jumlah pengunjung yang datang cukup banyak. Umumnnya dari setiap unit usaha hanya dibutuhkan tenaga kerja 1-2 orang, sedangkan untuk pedagang keliling rata-rata dikelola sendiri oleh mereka.

Tenaga kerja lokal merupakan pihak yang secara tidak langsung mendapatkan dampak ekonomi dari keberadaan objek wisata ini yaitu melalui pendapatan yang mereka dapat dari pemilik unit usaha. Keterangan lebih lanjut tentang jumlah tenaga kerja di Danau Sebedang dapat dilihat pada Tabel 8.

Tabel 8. Jumlah Tenaga Kerja Total pada Unit Usaha di DWSS Tahun 2016 (Total Worker at Business Units in DWSS 2016 )

\begin{tabular}{lccc}
\hline \multicolumn{1}{c}{ Unit Usaha } & tenaga kerja $($ Org $)$ & Hari kerja & Jam Kerja \\
\hline Warung & 1 & setiap hari & $7-8$ jam \\
Rumah Makan & 3 & $1-2$ hari & 10 jam \\
Tempat Penginapan & 1 & setiap hari & 12 jam \\
Kafe & 2 & setiap hari & $5-6$ jam \\
Penjaga loket & 3 & setiap hari & $5-7$ jam \\
\hline
\end{tabular}

Sumber: Data diolah 2016. 
Data tabel 8, rumah makan dan penjaga loket merupakan unit usaha yang paling tinggi menyerap tenaga kerja lokal. Hal ini disebabkan karena jumlah jam kerjanya yang lebih panjang, dan bahkan ada yang tinggal di objek wisata tersebut.

\section{c. Dampak Ekonorni Lanjutan (Induced Impact)}

Kegiatan wisata tidak hanya menghasilkan dampak langsung dan tidak langsung, tetapi juga menghasilkan dampak lanjutan (induced). Dampak ini merupakan dampak lanjutan dari pengeluaran yang dilakukan oleh tenaga kerja lokal di objek wisata ini. Dampak ini berasal dari pengeluaran sehari-hari tenaga kerja lokal. Selaras dengan penelitian Anisah dan Riswandi (2015), semakin tinggi jumlah pendapatan yang dimiliki responden maka akan semakin tinggi pula biaya makan yang dikeluarkan. Penelitian ini dimana sebagian besar dari proporsi pengeluaran tenaga kerja digunakan untuk kebutuhan pangan yaitu sebesar 58,34\%.Setelah itu digunakan untuk biaya transportasi yaitu sebesar 23,78\%. Sisanya digunakan untuk kebutuhan lainnya, seperti biaya listrik, jajan anak dan lainlain. Proporsi rata-rata pengeluaran tenaga kerja di objek wisata ini dapat dilihat pada Tabel 9.

Tabel 9. Proporsi Pengeluaran Tenaga Kerja di DWSS Tahun 2016 (Proportion of Worker Expenditures in DWSS 2016 )

\begin{tabular}{|c|c|}
\hline Karakteristik & Proporsi $(\%)$ \\
\hline Kebutuhan pangan & 58,34 \\
\hline Biaya transportasi & 23,78 \\
\hline Biaya lainnya & 17,87 \\
\hline
\end{tabular}

Sumber: Data diolah, 2016.

\section{d. Nilai Pengganda dari Pengeluaran Pengunjung}

Semakin banyak permintaan wisatawan maupun industri pariwisata, maka dapat semakin meningkatkan produktifitas sektor-sektor ekonomi. Hal ini menunjukkan bahwa pariwisata memiliki efek multiplier yang kuat terhadap sektor-sektor lainnya (Utama, 2006). Nilai efek pengganda (mulltiplier) dapat digunakan untuk mengukur seberapa besar dampak ekonomi dari pengeluaran pengunjung yang digunakan selama mereka melakukan kegiatan rekreasi. Berdasarkan META (2001)terdapat dua ukuran dalam mengukur dampak ekonomi pariwisata pada tingkat lokal yaitu: (1) Keynesian Local Income Multiplier, yaitu nilai yang menunjukkan berapa besar pengeluaran pengunjung berdampak pada peningkatan pendapatan masyarakat lokal dan (2) Ratio Income Multiplier, yaitu nilai yang menunjukkan seberapa besar dampak langsung yang dirasakan dari pengeluaran pengunjung berdampak terhadap perekonomian lokal. Nilai pengganda tersebut mengukur dampak tidak langsung dan dampak lanjutan (induced). Keterangan dapat dilihat pada Tabel 10. 
Tabel 10. Nilai Multiplier dari Arus uang yang Terjadi di DWSS Tahun 2016 (The Multiplier Value of the Cash Flow that Occurs in DWSS 2016)

\begin{tabular}{lr}
\hline \multicolumn{1}{c}{ Kriteria } & Nilai \\
\hline Keynesian Income Multiplier & 1,24 \\
Ratio Income Multiplier Tipe 1 & 1,12 \\
Ratio Income Multiplier Tipe 2 & 2,25 \\
\hline
\end{tabular}

Sumber: Data diolah, 2016.

Berdasarkan data yang diperoleh untuk menentukan besarnya dampak ekonomi di objek wisata Danau Sebedang, didapat nilai Keynesinn Income Multiplier yaitu sebesar 1,24 yang artinya peningkatan pengeluaran pengunjung sebesar 1 rupiah akan berdampak pada peningkatan pendapatan masyarakat lokalsebesar 1,24 rupiah. Dampak ekonomi lanjutan dari pengeluaran pengunjung juga dirasakan oleh pemilik unit usaha berupa keuntungan yang diterima. Selanjutnya dampak ekonomi dirasakan juga oleh tenaga kerja lokal di objek wisata yaitu berupa upah yang mereka dapatkan dari pemilik unit usaha. Nilai Ratio Income Multiplier Tipe 1 adalah 1,12 yang artinya peningkatan 1 rupiah pendapatan pemilik usaha akan mengakibatkan peningkatan sebesar 1,12 rupiah pada dampak langsung dan tidak langsung (berupa pendapatan pemilik unit usaha dan tenagakerja lokal).

Nilai Ratio Income Multiplier Tipe 2 sebesar 2,25 yang artinya peningkatan 1 rupiah pendapatan pemilik unit usaha akan mengakibatkan peningkatan sebesar 2,25 rupiah pada dampak langsung, tak langsung dan lanjutan (berupa pendapatan pemilik usaha, tenaga kerja dan pengeluaran konsumsi di tingkat lokal). Berdasarkan hasil diatas dapat disimpulkan, bahwa keberadaan objek wisata inisecara nyata memberikan dampak ekonomi terhadap perekonomian masyarakat lokal sekitar lokasi tersebut. Nilai multiplier ini masih dapat ditingkatkan seiring dengan pengembangan objek wisata ini, peningkatan pemberdayaan masyarakatlokal dan penyediaan barang yang diperlukan pengunjung oleh unit usaha yangada. Hal ini dapat meningkatkan proporsi pengeluaran pengunjung di objek wisata yang berpengaruh baik secara langsung ataupun tidak langsung terhadap perekonornian masyarakat lokal sekitar.

\section{Kesimpulan}

Berdasarkan hasil penelitian dan analisis data dampak keberadaan objek wisata alam Danau Wisata Sejarah Sebedang terhadap masyarakat sekitar dapat disimpulkan:

1. Pengunjung objek wisata Danau Sebedang umumnya didominasi kelompok masyarakat berusia antara 25 tahun - 35 tahun, dengan tingkat pendidikan SLTA dan Perguruan Tinggi, rata-rata tingkat pendapatan mereka adalah Rp. $1.600 .000,00$ sampai Rp 2.000.000,00 per bulan. Sebagian besar dari pengunjung sudah berkeluarga dan mempunyai 
tanggungan. Sebagian dari pengunjung berasal dari Sambas dan sekitarnya dan pada umumnya pengunjung datang dengan rombongan menggunakan kendaraan pribadi

2. Persepsi pengunjung terhadap sarana dan prasarana di objek wisata Danau Sebedang berada pada penilaian relatif baik, tetapi pada beberapa sarana diperlukan perbaikan seperti toilet, tempat sampah, dan warungwarung yang berada ditepian danau. Sedangkan persepsi untuk panorama danau, kebersihan, sikap masyarakat, pengelola dan kebersihan berada pada penilaian baik.

3. Faktor-faktor yang mempengaruhi permintaan rekreasi ke objek wisata Danau Sebedang adalah biaya perjalanan, dan waktu tempuh sedangkan pendapatan, umur, jumlah tanggungan, jumlah rombongan dan pengetahuan pengunjung tidak mempengaruhi kunjungan kunjungan ke objek wisata DWSS.

4. Keberadaan objek wisata Danau Sebedang ini rnemberikan dampak ekonomi bagi masyarakat lokal sekitar. Dampak ekonomi langsung yang berupa pendapatan pemilik unit usaha yaitu sebesar 71,8 \%. sedangkan dampak tidak langsung yang berupa pendapatan tenaga kerja masih sangat rendah yaitu sebesar $4,79 \%$. Dampak induced yang berupa pengeluaran tenaga kerja sebesar 58,34\% digunakan untuk kebutuhan pangan. Nilai Keynesian lncome Multiplier adalah 1,24, Ratio
Income Multiplier Tipe 1 adalah 1,12 dan Ratio Income Multiplier Tipe 2 adalah 2,25.

\section{Saran}

1. Pemilik unit usaha diharapkan dapat lebih memenuhi kebutuhan pengunjung, misalnya penyediaan jenis makanan dan minuman yang lebih bervariasi, penyewaan jasa yang lebih beragam dan lainnya.

2. Pihak pengelola diharapkan dapat meningkatkan manajemen pengelolaan demi kemajuan objek wisata ini. Selain itu diharapkan agar lebih meningkatkan usaha pemberdayaan masyarakat lokal sekitar.

3. Pemerintah daerah harus dapat lebih meningkatkan kegiatan promosi untuk memperkenalkan objek wisata Danau Sebedang ini melalui media cetak dan elektronik.

\section{Ucapan Terima Kasih}

Saya ucapkan terima kasih kepada pengelola Danau Wisata Sejarah Sebedang, yang telah memberikan kesempatan kepada saya untuk melakukan penelitian pada lokasi tersebut.

\section{DAFTARPUSTAKA}

Azahra, Khadiyanto. 2013. Pengaruh Keberadaan Desa Wisata Terhadap Peningkatan Kesejahteraan Masyarakat. Jurnal Perencanaan Wilayah Dan Kota. 1(1).

Anisah. Riswandi. 2015. Pantai Lampuk Dan Dampaknya Terhadap Perekonomian Masayakat. Jurnal Ekonomi Dan Kebijakan Publik. 2(2):2442-7411. 
Ardahaey, Tohidy. 2011. Economic Impacts Of Tourism Industry. International Journal of Business and Management. 6( 8).

Faizun. 2009. Dampak Perkembangan Kawasan Wisata Pantai Kartini Terhadap Masyarakat Setempat Di Kabupaten Jepara. Tesis. Program Pascasarjana Magister Teknik Pembangunan Wilayah Dan Kota Universitas Diponegoro, Semarang.

Hary. 2017. Dampak Pengembangan Desa Wisata Nglanggeran Terhadap Ekonomi Masyarakat Lokal. Jurnal Pariwisata. 3 (2), 2528-2220

META. 2001. Planning For Marrine Ecouturism In The EU Atlantic Area. University of the West of England, Bristol.

Robihah. 2014. Manfaat Wisata Alam Danau Wisata Sejarah Sebedang Kecamatan Sebawi. Jurnal Hutan Lestari. Vol. 2 No. 3. Hal 3.

Sigit. 1994. Perkembangan Dampak Ekonomi Pariwisata.Jurnal PWK. Vol.5 No. 5 Hal: 25-26.

Umar. 1996. Metode Penelitian untuk Skripsi dan Tesis Bisnis, Rajagrafindo Persada, Jakarta.

Utama, Suyana. 2006. Pengaruh Perkembangan Pariwisata Terhadap Kinerja Perekonomian Dan Perubahan Struktur Ekonomi Serta Kesejahteraan Masyarakat Di Provinsi Bali. Disertasi. Fakultas Ekonomi Universitas Udayana, Denpasar.

Vanhove. 2005. The Economy of Tourism Destinations. Elsevier Buttherworth. Burlington.
Widya. 2012. Analisis Peran Industri Pariwisata Terhadap Pendapatan Asli Daerah Kabupaten Wonosobo. Jurnal Ilmiah. Vol. 3 No. 2 hal:2-3.

Yulendra. 2015. Dampak Persepsi Masyarakat Lokal Terhadap Keberadaan BAR di Kawasan Wisata Sengingi Lombok Barat. Jurnal Media Bina Ilmiah. Vol. 9 No. 1 Hal35-36. 